\title{
Prodicus on the Rise of Civilization
}

Religion, Agriculture, and Culture Heroes

\section{Stavros Kouloumentas}

\section{(2) OpenEdition}

Journals

Electronic version

URL: https://journals.openedition.org/philosant/1026

DOI: 10.4000/philosant.1026

ISSN: 2648-2789

\section{Publisher}

Éditions Vrin

\section{Printed version}

Date of publication: 1 November 2018

Number of pages: 127-152

ISBN: 978-2-7574-2372-1

ISSN: 1634-4561

\section{Electronic reference}

Stavros Kouloumentas, "Prodicus on the Rise of Civilization ", Philosophie antique [Online], 18 | 2018,

Online since 01 November 2019, connection on 03 December 2022. URL: http://

journals.openedition.org/philosant/1026 ; DOI: https://doi.org/10.4000/philosant.1026

\section{(c) $)(9)$}

Creative Commons - Attribution-NonCommercial-NoDerivatives 4.0 International - CC BY-NC-ND 4.0 https://creativecommons.org/licenses/by-nc-nd/4.0/ 


\section{PRODICUS ON THE RISE OF CIVILIZATION Religion, agriculture, and culture heroes}

Stavros Kouloumentas

Center for Hellenic Studies, Harvard University

skouloumentas@gmail.com

RÉSUMÉ. Prodicus est réputé pour avoir formulé une théorie nouvelle sur les origines de la croyance religieuse, qui a parfois été taxée d'athéisme dans l'Antiquité, notamment par les épicuriens. Il suggère que les hommes ont d'abord considéré comme des dieux des choses qui étaient utiles à leur survie, comme les fruits et les rivières, et qu'à un stade plus avancé, ils ont déifié des héros culturels, comme Déméter et Dionysos. Je suggère d'abord que la théorie de Prodicus peut être reliée à d'autres doctrines qui lui sont attribuées, en particulier au discours concernant « le choix d'Héraclès » et à un fort intérêt pour l'étymologie des mots. En outre, je soutiens que les différentes représentations de sa théorie reflètent le débat entre les épicuriens et les stoïciens concernant l'implication des dieux dans les affaires humaines et cosmiques. Un examen des preuves fragmentaires montre que Prodicus était un penseur qui était intéressé par les origines de la civilisation en général, et ainsi que sa théorie était partie intégrante d'un projet de grande envergure cherchant à expliquer plusieurs aspects interconnectés de la vie sociale en termes rationnels.

Summary. Prodicus gained a reputation for formulating a novel theory concerning the origins of religious belief, sometimes labelled as atheistic in antiquity, notably by the Epicureans. He suggests that humans initially regarded as gods whatever was useful for their survival such as fruits and rivers, and in a more advanced stage they deified culture heroes such as Demeter and Dionysus. I first suggest that Prodicus' theory can be connected with other doctrines attributed to him, especially the speech concerning "Heracles' choice" and the keen interest in the etymology of words. Moreover, I argue that the different representations of his theory reflect the debate between the Epicureans and the Stoics concerning the involvement of gods in human and cosmic affairs. An examination of the fragmentary evidence shows Prodicus to be a thinker who was interested in the rise of civilization in general, and so his theory was part and parcel of a large-scale project to explain several interconnected aspects of social life in rational terms.

Philosophie antique, ${ }^{\circ} 18$ (2018), 127-152 

Three authors who were active in classical Athens seem to have been familiar with the ideas of Prodicus of Ceos (c. 465-395 BC)*, who was labelled as one of the first atheists in the Hellenistic era. ${ }^{1}$ Xenophon preserves a rhetorical display of Prodicus in which the young Heracles meets Virtue and Vice, two ladies of different appearance and character who in turn make cases for living in accordance with their moral principles. ${ }^{2}$ Aristophanes, on the other hand, describes him as an "expert in celestial things" and corruptor of citizens and constructs a fanciful cosmogony as an alternative to Prodicus' account. ${ }^{3}$ For his part, Plato presents Prodicus as a successful teacher who attempts subtle distinctions between near-synonyms and is obsessed with

* The completion of this paper was possible thanks to the support of the research programme "Religions et Sociétés dans le Monde Méditerranéen: Rationalité et Religion", under the supervision of Jean-Baptiste Gourinat at the Labex Resmed (ANR-10-LABX-72), and a fellowship at the Center for Hellenic Studies in Washington DC. I have presented versions of this paper in Patras, Rethymnon, Paris, Bryn Mawr Pennsylvania, and Washington DC. I am grateful to the participants for their comments, Philosophie Antique's referees, as well as Chloe Balla, Jean-Baptiste Gourinat, Rhodes Pinto, Spyridon Rangos, Maria Michela Sassi, David Sedley, and James Warren who commented on earlier drafts. Christian Vassallo kindly supplied me with his paper on Prodicus and provided feedback. Despite the fact that the two of us worked independently from each other, we draw similar conclusions as to Prodicus' contribution to the criticism of traditional religion.

1. References to Presocratic testimonies and fragments are made in accordance with Diels \& Kranz 1951-1952 [hereafter DK]. The texts pertaining to Prodicus' theory are printed together (DK $84 \mathrm{~B} 5$ ), but significant material is omitted or quoted from obsolete editions. The collection of Untersteiner 1961, p. 190-196, is more complete, although an important text from Philodemus' On Piety is not included. The monograph of Mayhew 2011, p. 44-50, 175-194, provides the full textual evidence (T 70-78) and extensive commentary. See also Laks \& Most 2016, p. 434-439 (D15-18) and p. 466-471 (R8, R11-13). I quote PHerc. 1077, col. XIX from Obbink 1996, p. 142-143; PHerc. 1428, fr. 19 from Schober 1988, p. 115; and PHerc. 1428, cols. II.28-III.13 from Henrichs 1975, p. 116. On a new reconstruction of the texts from On Piety see Vassallo in this volume, p. 153-168.

2. DK 84 B2. Xenophon also refers to the high fees charged by Prodicus (DK 84 A4a).

3. DK 84 A5, A10. 
the correct use of words. ${ }^{4}$ Each of these contemporaries of Prodicus provides valuable evidence concerning his wide interests, ranging from rhetoric and ethics to natural philosophy and language, but makes no explicit reference to his attempt to explain how the belief in divine beings arose.

It is authors who flourished in the Hellenistic era (Philodemus, Cicero, Sextus Empiricus) or even later (Themistius, Minucius Felix) and are engaged in reviewing the theology of their predecessors that mention Prodicus' theory. The aim of this paper is to show that, despite their thematic variations, the reports of Xenophon, Aristophanes, and Plato can be connected with and supplement the sources dealing with Prodicus' theory. More specifically, I suggest that Prodicus employs his linguistic skills to reveal the true nature of gods and explains the emergence of religion as part of a cultural narrative that describes the genesis of social institutions and the formation of moral values and culture heroes. As part of this attempt to reassess the textual evidence pertaining to Prodicus, I turn to the main witnesses to his theory in order to examine how it was intermingled with the theological debates of Hellenistic philosophers. I argue that the Epicureans interpreted Prodicus' theory quite differently from the Stoics, since the former considered him to be one of the first champions of atheism, whereas the latter recognized some elements of their own arguments for the existence and benevolence of the god in his anthropological interpretation of religion. ${ }^{5}$

\section{The emergence of religion}

Early Greek philosophers attributed divine features to their principles that were supposed to be immortal, omnipotent, and omniscient. They were thus replacing the Olympian gods with powers that permeate and control the natural world, like the infinite (DK 12 A15), the Mind (DK 59 B12), and air (DK 64 B5). ${ }^{6}$ As part of this rationalising approach, the belief in divine beings was the subject of a growing amount of reflection and criticism that often resulted in bold statements as to the true nature of gods. Religion was interpreted as a human invention that reflected the awe of the earliest humans of celestial phenomena (Democritus), their gratitude to commodities and benefactors (Prodicus), or their fear of a powerful agent who keeps an eye on everything (Critias).

To focus on Prodicus' theory, a number of Hellenistic philosophers report

4. DK 84 A2-4, A11, A13-18, A20. The few references of Aristotle (DK 84 A12, A19) accord with the Platonic reports.

5. For a survey of atheism in antiquity see Bremmer 2007; Sedley 2013b; Whitmarsh 2015.

6. Cf. Jaeger 1947. 
that he tried to trace the origins of religious belief at the dawn of civilization: ${ }^{7}$

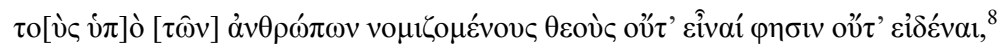

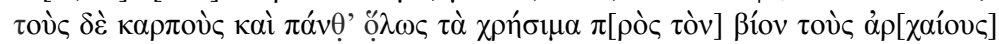

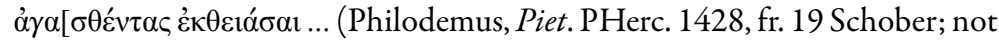
in DK).

[sc. Prodicus] says that the gods recognized by humans neither exist nor have knowledge, but the ancients out of admiration deified the fruits of the earth and virtually everything that contributed to their livelihood ...

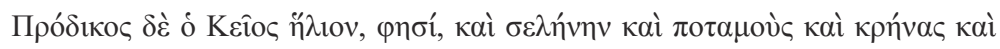

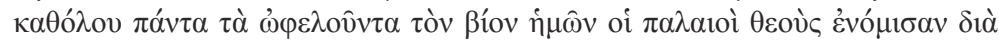

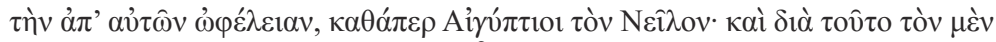

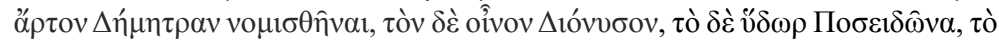
$\delta \dot{\varepsilon} \pi \hat{v} \rho$ "H Empiricus M. IX.18; cf. IX.39, 41, 51-52).

Prodicus of Ceos says that the ancients considered as gods the sun, the moon, the rivers, the springs, and in general all the useful things for our life because of the benefit derived from them, just as the Egyptians [sc. considered as god] the Nile. And [sc. he says that] for this reason they considered that bread was Demeter, wine Dionysus, water Poseidon, fire Hephaestus, and so on for each of the things that are useful.

Quid? Prodicus Cius, qui ea quae prodessent hominum vitae deorum in numero habita esse dixit, quam tandem religionem reliquit? (DK 84 B5 = Cicero ND I.118).

What? Prodicus of Ceos, who said that those things which benefit human life have been counted among gods, left what of religion?

According to Prodicus, the earliest humans had the tendency to deify useful things provided by nature. His examples include the nourishing stuffs of the earth, the elemental forces that sustain life, the sun that provides humans with light and warmth, the moon whose regular movements help them to establish a rudimentary calendar, as well as the rivers and the springs that supply them with water and sustain vegetation. Indeed, the physical entities and forces mentioned by Prodicus were honoured as the divinities of the heavens (the Sun, the Moon), the water (Poseidon, the Nymphs, the

7. A full examination of Prodicus' theory, with particular emphasis on its reception in antiquity and the problems pertaining to the textual evidence, can be found in Henrichs $1975,1976,1984$.

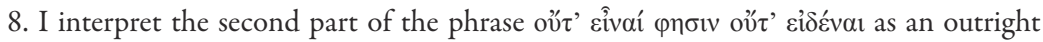
denial of divine intelligence, which was traditionally assigned to the gods (Od.IV.379; Hesiod Op. 267; DK 21 B24), but the text can also be translated as expressing a sort of radical atheism that supersedes Protagoras' agnosticism: "[sc. Prodicus] says that the gods recognized by humans do not exist and that he does not recognize them". Detailed discussion in Henrichs 1976 who reconsiders the translation and interpretation adopted in Henrichs 1975. 
river Acheloos), and the earth (Demeter, the Horai, the Earth Mother). ${ }^{9}$ The genesis of religion is thus interpreted as manifesting our gratitude to commodities that contribute to the survival of humankind.

In a more advanced stage, which presupposes the existence of settled living and farming, humans deify those who invent useful things for all members of their community:

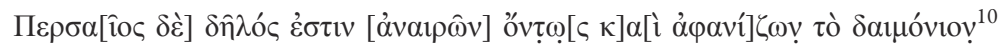

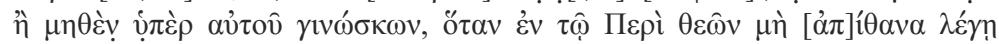

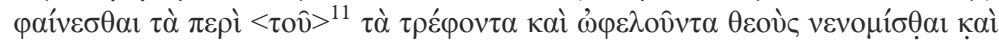

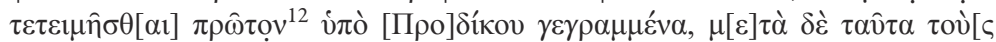

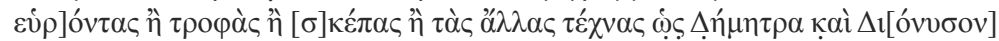

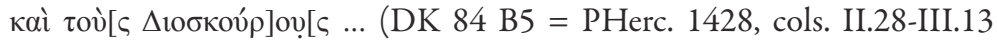
Henrichs).

It is clear that Persaeus really abrogates and demolishes the divine or knows nothing about it when in $O n$ Gods he says that Prodicus was not unpersuasive in writing that the things which nourish and benefit were first considered and honoured as gods, and, after these things, those who discovered foods or shelters or the other arts, like Demeter, Dionysus, and the Dioscuri ...

The gratitude of humans is now expressed towards culture heroes. Instead of worshipping the crops and the natural forces providing them, for instance, they worship the inventors of the new techniques of acquiring food and improving their diet. ${ }^{13}$ Practical arts were thus associated with beneficient

9. If the reference to the Nile goes back to Prodicus, it seems likely that he provides a general account of the origins of religious belief across different cultures. It could not have escaped his attention that in the religion of the Near East the celestial bodies - the sun in particular - and the great rivers play a prominent role as the life-bearing forces that guarantee the social order.

10. Vassallo suggests that the opening section of the text deals with Persaeus' concep-

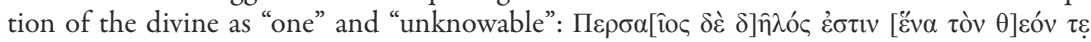

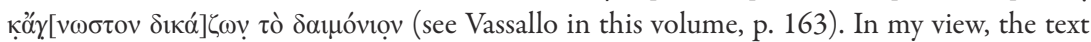
may in fact refer to the benevolent nature of the divine ( $c f$. Eusebius PE XV.15.5 on the attributes of the god), which, according to Persaeus, was anticipated by Prodicus: $\Pi \varepsilon \rho \sigma \alpha[\hat{i} \circ \varsigma \delta \grave{\varepsilon} \delta]$

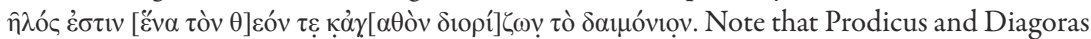
of Melos seem to believe that "the gods are always good" in the surrounding lines: $\kappa \hat{\alpha} \gamma[\alpha \theta]$ ov̀

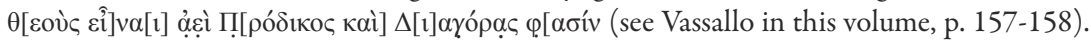
On Persaeus' interpretation of Prodicus' theory see below p. 146-149.

11. On Diels's addition see Henrichs 1975, p. 116, n. 81.

12. The exact meaning of the text is unclear: if we construe $\pi \rho \hat{\tau} \tau$ ọ with the infinitives

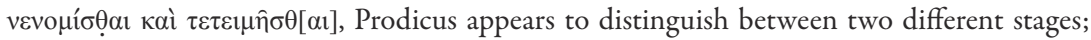

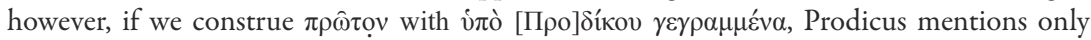
the deification of commodities and Persaeus supplements the doctrine of his forerunner by referring to the deification of benefactors. Henrichs 1975, p. 107-123, provides convincing arguments to adopt the former interpretation.

13. There are two ways to understand the deification of benefactors like Dionysus. (1) There was an actual person who invented wine and viniculture, and after his death and upon 
gods who hold a prominent status in the Olympian pantheon, including Demeter (the provider of crops and inventor of agriculture), Dionysus (the inventor of wine and viniculture), and the Dioscuri (the horse tamers and protectors of sailors). 14

It is worth noting that the Stoic Persaeus, as reported by Philodemus, is the sole author who attributes both stages to Prodicus and proposes a shift in the objects of worship. Both Cicero and Sextus Empiricus suggest that Prodicus merely refers to the deification of commodities and they examine the deification of exceptional individuals in connection with Euhemerus ${ }^{15}$ (Cicero ND I.118-119; Sextus Empiricus M. IX.17, 50-52), while Minucius Felix reports that Prodicus deals with culture heroes who were deified posthumously (Minucius Felix Oct. XXI.2). In fact, Cicero and Minucius Felix credit Persaeus, who appears to endorse Prodicus' theory to some extent in his $O n G o d s$, with the idea that commodities and benefactors were deified; however, they make no distinction between a primitive and a more advanced stage (Cicero ND I.38; Minucius Felix Oct. XXI.3). Despite these variations, there is no reason to challenge Persaeus' report. ${ }^{16} \mathrm{He}$ claims to have access to first-hand material, whereas the knowledge of the other witnesses to Prodicus' theory is indirect: Sextus Empiricus draws from the lost treatise Concerning Atheism composed by the Academic Sceptic Clitomachus, ${ }^{17}$ and Cicero's doxographical account is chiefly based on the corresponding section of On Piety. ${ }^{18}$ Furthermore, the assumption that some gods were mortals who were deified on account of their outstanding acts is attested in several fifth-century authors. Herodotus, for instance, relates how Protaeus, the sea-god who was known for his transformations, became a king in Egypt (Herodotus II.112-119), and he suspects that Heracles, Dionysus, and Pan were originally humans (Herodotus II.146). Moreover, the idea that religion is gradually shaped fits with current theories put forward by Democritus, Protagoras, the unknown author of the Sisyphus fragment, and Moschion,

realisation of the benefits of his discovery, he was deified. (2) Humans expanded from mere worship of crops (grapes) to the worship of practical arts (viniculture) by fabricating some benefactor god. If (1), the veneration is mostly directed towards the benefactor. If (2), the veneration is mostly directed towards the benefit itself.

14. Prodicus' list of culture heroes may also include Aristaeus who taught humans to hunt, cultivate olives, and keep bees. It is often reported that Ceos, the birthplace of Prodicus, suffered from drought and received through Aristaeus rain and winds (Apollonius Rhodius Arg. II.519-530; Diodorus Siculus IV.81.5-82.6; Virgil Georg. IV, 281-558). Cf. Nestle 1936, p. $151-152$.

15. On Euhemerus, who was active after Prodicus and claimed that the gods were originally powerful rulers, see Winiarczyk 2013.

16. Guthrie 1969, p. 239-241; Henrichs 1975, p. 113-115.

17. Henrichs 1976, p. 30-31; Winiarczyk 1976.

18. Obbink 2001. As far as Minucius Felix is concerned, Henrichs 1975, p. 114-115, notes that we cannot be sure as to his source of information. 
all of whom describe the rise of civilization from a bestial state of living. In the same context Prodicus seems to have formulated his own theory (note the references of Philodemus and Sextus Empiricus to "the ancients", as well as the distinction between $\pi \rho \hat{\tau} \tau o$ v and $\mu[\varepsilon] \tau \grave{\alpha} \delta \dot{\varepsilon} \tau \alpha \hat{\tau} \tau \alpha$ in On Piety), arguing that the belief in divine beings is shaped with reference to the living conditions of humankind. The need to obtain resources makes the earliest humans deify those aspects of nature that maintain their survival. After the formation of communities they create gods who reflect the evolution of humankind and its dependence on practical arts rather than on nature.

\section{Reconstructing the Seasons: an account of cultural evolution?}

Apart from the aforementioned points we know next to nothing about the content and scope of the work in which Prodicus formulated his theory. We can, however, speculate as to these issues by taking into account the title of Prodicus' treatise and the identity of the gods who are interpreted as constructs of grateful humans.

Prodicus composed a work entitled the Seasons ( $\left.{ }^{\mathrm{i}} \Omega \rho \alpha \mathrm{l}\right)$ that included encomia on exceptional individuals, like Heracles (DK 84 B1). ${ }^{19}$ The relatively uncommon title refers to the goddesses who were initially associated with the seasonal cycle and the process of flourishing and were gradually elevated to the supervisors of social order, especially peace and fair administration. ${ }^{20}$ The twofold dimension of the Horai can be seen in a speech that extols the importance of agriculture to the formation of religious belief. Themistius appeals to the Horai and other divinities associated with the cultivation of the soil and notes that Prodicus attributes all religious practices, mysteries, and festivals to the benefits of agriculture:

Let the gods who oversee agriculture to be summoned to help with this speech and what is strongest of all the Muses and the Muse-leader himself, since they receive the annual return from agriculture - libations and sacrifices and banquets and all that the Horai make grow from the earth - not only for this, but also for everything that humans have from god. If we also summon

19. Prodicus is also credited with the following works: a treatise on the nature of things, as noted by Cicero and Galen (DK 84 B3); a treatise On the Nature of Man, from which Galen quotes a linguistic correction (DK 84 B4). The first work may be (i) a treatise on its own right, (ii) the first part of a treatise, divided into parts dealing with the macrocosm (On Nature) and the microcosm (On the Nature of Man), or (iii) the introductory section of the Seasons. Mayhew 2011 p. XXI-XXIII, offers an attractive reconstruction of the Seasons, suggesting that it commences with the nature of primitive men and the emergence of religion and then turns to the stages of human life.

20. The names of the Horai varied but were normally considered to be three: either Thallo-Auxo-Carpo, the goddesses of seasonal changes and growth (Pindar Ol. XIII.17; Pausanias IX.35.2), or Eunomie-Dike-Eirene, the daughters of Zeus and Themis and the supervisors of social order (Hesiod Th. 901-903). Cf. Cornutus ND 57.6-8. 
Dionysus, the Nymphs, Demeter's daughter, the rain-bringing Zeus, and nourishing Poseidon, then we approach the rites and shall invoke in our account the wisdom of Prodicus, who derived all religious practices of humans and mysteries and festivals and rites from the goods of agriculture, believing that the notion ("vvolav) ${ }^{21}$ of gods came to humans from this source and making it the guarantee of all piety (DK 84 B5 = Themistius Or. XXX, 349a-b).

Being the main art that supplies humans with useful things, agriculture encourages them to worship what grants these goods. The religious sentiment is progressively shaped and transformed into rites by expressing the hopes, the agonies, and the gratitude of farmers not only to the impersonal forces of vegetation and fertility but also to the resourceful inventors who help them to maintain and enhance their harvest.

The emphasis on the primacy of agriculture over religion reflects an effort to explain the origin of cultural conquests, trace their sequence, and assess their importance. Hence it can be argued that the Seasons contains a sort of cultural narrative, like other contemporary texts that refer to the rise of civilization. ${ }^{22}$ Unlike the accounts that describe the moral decline of humankind and the miseries of the present era (e.g. Hesiod's five ages), a prominent motif of several cultural narratives is the evolution of humans and the improvement to the means of securing nourishment as a result of their own efforts or the benevolent intervention of some divinity. The earliest humans were thought to live in scattered units and to be bereft of moral values and laws, feeding on whatever could be found in nature and suffering from cold weather and the attacks of wild beasts. These hardships made them come together and establish elementary means of survival and communication, thus gradually founding the fundamental elements of a community.

Such a cultural narrative seems to have been included in the lost treatise of Protagoras On the Original State of Things (DK $80 \mathrm{~B} 8 \mathrm{~b}$ ) from which Plato may well draw material in the Protagoras. According to the myth, as adapted in the Platonic dialogue, the worship of gods is an integral part of communal life and is placed alongside other achievements, such as language, house-building, clothing, and agriculture, which arise after Prometheus'

21. This is an emendation proposed by Diels and adopted by most scholars, including Untersteiner 1961 p. 196; Guthrie 1969 p. 239, n. 2; and Mayhew 2011 p. 193. The editors of the Orations (Dindorf, Schenkl-Downey-Norman) prefer the manuscript reading عv̋votav ("goodwill"). Cf. Laks \& Most 2016 p. 438.

22. This proposal was first formulated by Nestle 1936 ( $c f$. Nestle 1942 p. 351-360; Henrichs 1984 p. 141-143; Soverini 1998 p. 90-114), who reconstructs the content of the Seasons from Themistius' Orations, Xenophon's Oeconomicus, and the ps.-Platonic Axiochus and Eryxias. Nestle suggests that Prodicus used the concept of "usefulness" to stress the key role of agriculture in the rise of civilization and its primacy over other cultural conquests. On other accounts of cultural evolution see Guthrie 1969 p. 60-84. 
donation of fire and technical wisdom to the primitive men. ${ }^{23}$ The fragmentarily preserved work of Democritus on the development of humankind, as reported by Diodorus Siculus (who presumably offers a patchwork of accounts of cultural evolution), provides an explanation along the same lines. ${ }^{24}$ In a savage stage, humans nourish themselves with herbs and fruits found here and there, but they gradually learn from experience to store them and use practical arts. This step includes the cultivation of the soil for growing crops and rearing domestic animals: the man-collector becomes the man-farmer, and the nomad who has no permanent residence is replaced by the citizen who is attached to his homeland. An elaborate description of this transition can be found in a fragment of Moschion. ${ }^{25}$ After referring to the dietary customs of the earliest humans who lived similarly to animals (v. 1-17), Moschion cites the possible reasons for the cultural revolution (v. 18-22) and then turns to the invention of agricultural blessings bestowed by Demeter and Dionysus (v. 23-25). This stage is characterised by advances in agricultural techniques, the fortification of cities and sheltering of houses, the improvement of human diet, and the burial of the dead (v. 25-33). The care for the corpses is contrasted with the former state of violence and lawlessness and indicates that a set of moral and religious norms, including

23. DK $80 \mathrm{C} 1$ = Plato Prot. 322a3-8: "Since man had a share of the divine, he became, to begin with, the sole animal to recognize gods by virtue of his kinship with the god, and he undertook to build altars and statues of the gods. Through his skill he soon devised articulate speech and names for things, as well as invented houses, clothing, footwear, beds, and nourishment from the earth". On the value of the myth as a source of the historical Protagoras see Manuwald 2013.

24. DK 68 B5.1 = Diodorus Siculus I.8.1-7: "But they say that the first humans to be born led an undisciplined and bestial life, wandering scatteredly to secure their sustenance and taking for their food the tenderest herbs and the spontaneous fruits of trees [...]. So the first humans lived laboriously, for none of the utilities of life had been discovered: they wore no clothes, they knew nothing of dwellings or fire, and they had not the slightest concep-

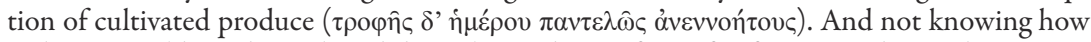
to harvest wild produce, they did not lay aside any fruits for future need. For this reason, many of them died during winter from the cold weather and lack of food. Later, gradually instructed by experience, they took refuge in caves during winter, and stored those fruits that could be preserved. Once fire and other utilities were recognized, the arts and whatever else could benefit communal life were slowly discovered [...] ". Detailed discussion of Democritus' theory and other parallel texts can be found in Cole 1967.

25. Moschion fr. 6.23-33 Snell: “Then was discovered holy Demeter's grain of tame nourishment and the sweet fount of Bacchus. The earth, once barren, began to be ploughed by yoked oxen, fortified cities arose, humans built houses covered all round, and they turned

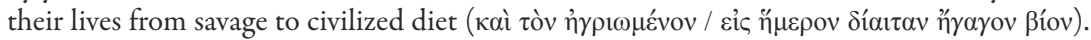
From this time custom ordained that they should hide the dead in tombs and give unburied bodies their portion of dust, leaving no visible reminder of their former impious feasts". The fragment derives from an unknown tragedy of the fourth or third century BC, but it is commonly agreed that Moschion's account of cultural evolution reflects the spirit of earlier theories. Cf. Guthrie 1969 p. 81-82. 
funeral rites, have been established. The survey of these accounts of cultural evolution confirms that religion and agriculture were often supposed to arise in an advanced stage of human history. Placed in this context, the Seasons describes the gradual transition of the primitive life of nomads and hunters to the organised life of agrarian society, which is based on the permanent residence in places suitable for cultivation, the domestication of animals, and the activities of communal life.

Let us now examine to what extent this tentative interpretation fits with the fragmentary and heterogeneous texts pertaining to Prodicus. The sole known fragment deriving from the Seasons is the famous speech concerning "Heracles' choice" (DK 84 B1). Xenophon offers a lengthy extract from Prodicus adapted to the dialectical plot of the Memorabilia (DK 84 B2 = Xenophon Mem. II.1.21-34). Xenophon's Socrates replies to Aristippus, the Cyrenaic philosopher according to whom the aim of human life is pleasure and the avoidance of toil and suffering. Thus Xenophon's Socrates focuses on the moral elements of the story that are suitable for his instruction without necessarily preserving its actual setting and full content. Even if "Heracles' choice" commences with the young Heracles at the crossroads, we lack the end of the story, namely the response of Vice to Virtue's rebuttal and the decision taken by Heracles, as well as the explanatory remarks, if any, offered by Prodicus. The story is usually interpreted as being a rhetorical display piece structured as a set of contrasting arguments or an allegory conveying a moral lesson. However, other interpretations cannot be excluded, since "Heracles' choice" is not preserved by other ancient reporters to check against the version of Xenophon. ${ }^{26}$

For example, the speech narrated by Xenophon's Socrates may be part of a general discussion concerning Heracles that aims to demythologise a popular hero and lay emphasis on his human status. The story contains no elements of the widespread narratives concerning Heracles' labours. Rather, Prodicus presents Heracles as a common man who has to choose between the difficulties of a virtuous life and the pleasures of an immoral life. It seems likely that he placed several culture heroes in a similar interpretative framework for, according to Plato's Symposium, Prodicus and other experts composed encomia on exceptional individuals (DK 84 B1). We may think

26. Scholars disagree as to whether "Heracles' choice" is a close approximation of Prodicus' own words (Sansone 2004, 2015; Tordesillas 2008) or contains Xenophon's terminology (Gray 2006) or is heavily rewritten by Xenophon (Dorion 2008). Xenophon was contemporaneous with Prodicus and may well preserve a speech that he himself heard in Athens (note the introductory remark: "Prodicus the wise, in his composition about Heracles, which he displayed to very many people", DK 84 B2 = Xenophon Mem. II.1.21). Xenophon's Socrates promises to quote Prodicus' speech to the best of his recollection (DK 84 B2 = Xenophon Mem. II.1.21), but admits that the original account was furnished with more resplendent expressions (DK 84 B2 = Xenophon Mem. II.1.34). 
of Demeter, Dionysus (the main providers of products associated with a civilized "tame" diet), and the Dioscuri, who are mentioned in connection with Prodicus' theory (DK 84 B5 = Philodemus Piet. PHerc. 1428, cols. II.28-III.13 Henrichs; Sextus Empiricus M. IX.18). ${ }^{27}$ How are these encomia connected with the discussion as to the formation of agrarian society and the emergence of religion?

The cultivation of the soil requires temperance, physical strength to overcome adversities, and respect to the divinities that reward the hard-working and fair individuals. These values are praised in "Heracles' choice" as necessary for those following a modest lifestyle and are sharply contrasted to the pursuit of pleasure and indolence promoted by Vice. ${ }^{28}$ They can hardly be separated from the fundamental concept of justice which ensures that each farmer enjoys the goods acquired by his own toil and not by immoral and violent means, as Hesiod emphasises in the Works and Days. ${ }^{29}$ The following extract from Virtue's speech is characteristic:

For the gods give to humans none of the things that are good and noble without labour and care. Rather, if you want the gods to be gracious to you, you must tend to the gods. If you wish to be loved by friends, you must do good deeds for your friends. If you desire to be honoured by some city, you must benefit the city. If you think that you deserve to be admired for your virtue by all of Greece, you must try to benefit Greece. If you want the earth to bear abundant crops for you, you must tend to the earth. If you think that you ought to become wealthy from livestock, you must care for your livestock.(DK 84 B2 = Xenophon Mem. II.1.28)

The exhortation commences with the rewards of the gods, turns to the honours acquired from social groups (friends, fellow-citizens, compatriots; note the emphasis on being beneficial to the city), and finally deals with the gifts of the nature. Agriculture and animal husbandry are not envisaged as

27. Sextus Empiricus refers to the identification of useful things with gods, but we cannot be sure that all of the pairs (Demeter-bread, Dionysus-wine, Poseidon-water, Hephaestus-fire; DK 84 B5 = Sextus Empiricus M. IX.18) go back to Prodicus. If he preserves Prodicus' own examples, the Seasons seems to contain material about several Olympian gods. See Euripides Ba. 274-285 on Demeter and Dionysus as the inventors of bread and wine respectively (cf. Dodds 1960 p. 104-106); Hymni Homerici XXII.4-5 on Poseidon: "In two respects, earth-shaker, the gods assigned you privilege: to be a tamer of horses and saviour of ships"; Hymni Homerici XX.1-7 on Hephaestus: "Of Hephaestus famous for contrivance you shall sing, clear-voiced Muse, of him who with steely-eyed Athena has taught glorious crafts to the humans on earth, who previously used to live in caves in the mountains like animals. But now through Hephaestus, the renowned technician, they have learnt crafts and pass their lives at ease in their own houses the whole year through".

28. The associates of Vice live without toils, and are not involved in military and public affairs. They always choose what is most delightful and profitable and so enjoy the goods produced by others (DK 84 B2 = Xenophon Mem. II.1.23-6).

29. Hesiod Op. 213-335. Cf. Gagarin 1973. 
merely practical arts but have also a moral and political dimension. They lead to the formation of a solid class of citizens who work hard, refrain from enjoying pleasures, respect their friends, defend the interests of the city and the nation to which they belong, and represent the embodiment of the Horai in communal life: good-order (Eunomie), justice (Dike), and peace (Eirene). The post-mortem reward of these exceptional individuals is mentioned at the end of Virtue's speech:

And whenever their appointed end comes, they do not lie forgotten without honour but flourish remembered, celebrated in song for all time ( $\dot{\alpha} \lambda \lambda \grave{\alpha} \mu \varepsilon \tau \grave{\alpha}$

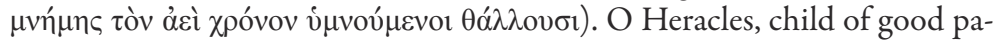
rents, by working hard at such things it is possible for you to possess the most blessed happiness. (DK 84 B2 = Xenophon Mem. II.1.33)

The concluding remarks of Virtue seem to allude to the potential apotheosis of exceptional individuals. Those who adhere to the lifestyle proposed in her instruction gain reputation among people, and their deeds are celebrated in hymns and stories. This seems to be the first step towards apotheosis for the traces of culture heroes are gradually lost, while their acts become legendary as they are transmitted from generation to generation and become known in different places. It is interesting that the speech, as preserved by Xenophon, is abruptly stopped here without giving some hint as to how Prodicus interpreted "Heracles' choice". Evidence from other speeches that deal with mythical figures, such as the Encomium of Helen and the Defence of Palamedes of Gorgias (DK 82 B11-11a), indicates that the so-called "sophists" used to challenge the common narratives concerning the role of legendary figures of the past and tried to draw attention to elements not recognized by their audience. Seen from this perspective, the inclusion of Heracles in a treatise that explained the origins of religious belief in conjunction with the rise of civilization denotes that Prodicus was interested in the representation of Heracles as a culture hero and wished to reveal his actual status: a virtuous mortal who was deified posthumously by his admiring contemporaries. ${ }^{30}$

\section{Prodicus on the gods and his contemporaries}

Three objections can be raised against the proposal that Prodicus put forward a cultural narrative in the Seasons: first, the story narrated by Xenophon's Socrates presents the gods as superior forces who oversee moral affairs and not as a human invention; second, there is no sufficient evidence

30. The divine status of Heracles was often suspected. Pindar calls him a "hero-god" (Pindar N. III.22), and Herodotus distinguishes between the sanctuaries of the god Heracles and those of the hero Heracles (Hdt. II.42). Diodorus Siculus mentions Heracles, Dionysus, and Aristaeus as examples of benefactors who were honoured as gods (Diodorus Siculus VI.1.2). Cf. Cornutus ND 63.3-12. 
that Prodicus was interested in the origins of things, like his forerunners; third, Plato, the main witness to the sophistic movement, refers mainly to the linguistic skills of Prodicus.

To begin with the first point, the gods are mentioned as the supervisors of noble deeds and dispensers of goods in the twofold presentation offered by Virtue, the personification of righteousness. According to Virtue, humans should tend to the gods in order to acquire their grace (DK 84 B2 = Xenophon Mem. II.1.27-28). Virtue also claims that she is connected with the gods, whereas Vice has been expelled from their company (DK 84 B2 = Xenophon Mem. II.1.31-33). These references in a speech attributed to Prodicus seem incompatible with the proposal that the Seasons included a theory on the emergence of religion which was often interpreted by ancient reporters as denying the existence of the gods.

It can be argued that the alleged atheism of Prodicus is due to a false generalisation of his inference that the worship of some gods reflects the human gratitude to commodities and benefactors. First of all, it is hard to accept that Prodicus dared to attack religious norms given his status as distinguished diplomat and learned teacher in Athens (DK 84 A1a-4) where Demeter and Dionysus, the prime examples of his theory, were highly honoured for their agricultural blessings and Theseus, a mythical figure comparable to Heracles, was considered the founding hero of the city. ${ }^{31}$ Denying openly the existence of these gods would scandalise most citizens, let alone Plato and Xenophon, two important witnesses to Prodicus' doctrines, who are known for their piety and conservatism. No ancient report suggests that Prodicus was prosecuted with the charge of impiety or faced public hostility as a result of his religious beliefs, as were other fifth-century thinkers (Anaxagoras, Protagoras, Diagoras of Melos, Socrates)..$^{32}$ In fact, he gained a reputation as one of the first atheists during the Hellenistic era when it was common to attribute this label to any thinker who reflected upon the divine, especially in the debates between rival philosophical schools. ${ }^{33}$

Themistius' report indicates that Prodicus' aim was not to undermine or ridicule religious belief but to interpret the worship of benefactor gods as a cultural phenomenon with positive effects on communal life. Thus Prodicus' inference that certain gods of the Olympian pantheon derive from human experience at the dawn of civilization is not necessarily a declaration that all

31. The dominant view is that Prodicus was an atheist (e.g. Mayhew 2011, p. 175-194). On a more sceptical approach, which I adopt in this paper, see Sedley 2013a, p. 330-331; Vassallo in this volume, p. 153-168.

32. The late report that Prodicus was condemned to drink hemlock because he corrupted the youth is a travesty of Socrates' death (DK 84 A1).

33. Prodicus is regarded an atheist by the Epicureans (Epicurus, Philodemus, the Epicurean spokesman in Cicero's De natura deorum) and the Sceptics (Clitomachus [?], Sextus Empiricus). The Stoic Persaeus, on the other hand, is sympathetic to Prodicus' theory. 
gods are fictional and non-existent. ${ }^{34}$ Rather, it can be understood as an effort to reinterpret and rationalise the divine by removing established misconceptions, like Xenophanes who criticised the anthropomorphic conception of the Olympian gods (DK 21 B11-16), and stressing the antithesis between

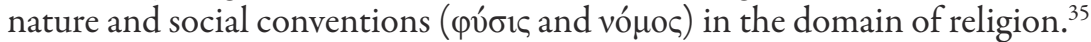
Philodemus' reference to "the gods recognized by humans" (Philodemus Piet. PHerc. 1428, fr. 19 Schober) shows that the emphasis of Prodicus is laid on the common beliefs about gods and not on the divine itself. Furthermore, if Prodicus' theory was constructed as a full account of religious belief, it would be unconvincing. Commodities and benefactors fail to capture the wide range of gods in Greek religion for people worshipped, inter alia, terrifying figures (the Erinyes, Styx), infernal divinities (Hades, Erebus), and personified concepts (Strife, Sleep, Harmony). On the other hand, if Prodicus' theory is interpreted as explaining the origin of some gods, especially those associated with agriculture, then its explanatory force cannot be denied. $^{36}$

Confirmation that Prodicus was interested in the emergence of religion as part of a large-scale project to explain the origins of things can be found in Aristophanes, who often parodies current philosophical ideas. In the Birds (performed in $414 \mathrm{BC}$ at the City Dionysia), the chorus rejects the traditional cosmogonies, chiefly represented by Hesiod's Theogony and Orphic poems, and constructs an alternative explanation of the genesis of the world which features birds rather than gods or powers. The cosmogony of the birds is introduced as follows:

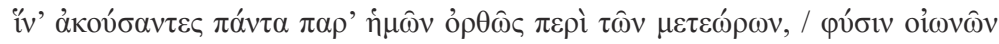

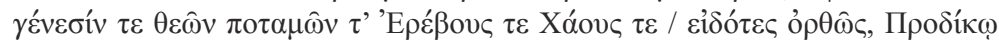

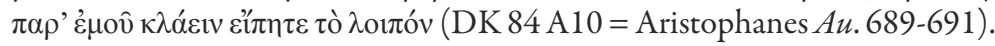

So that you may hear correctly from us everything about things in the heaven, and having correct knowledge of the nature of birds and the birth of gods, rivers, Erebus, and Chaos, tell Prodicus from me to weep now.

34. Sansone 2004 p. 140-142, suggests that "Heracles' choice" is a sample constructed for a general audience which displayed the rhetorical and teaching skills of Prodicus to potential pupils. Only those who could pay the fees for the highly priced speech (DK 84 A11-12) would learn about the true nature of gods.

35. Cf. Guthrie 1969 p. 55-134.

36. Assuming that Demeter, Dionysus, and the Dioscuri were the prime examples of Prodicus (DK 84 B5 = Philodemus Piet. PHerc. 1428, cols. II.28-III.13 Henrichs; Sextus Empiricus $M$. IX.18), his theory could have been easily misunderstood as denying the existence of all gods. Minucius Felix clearly refers to a specific group of benefactor gods: "Prodicus tells of the apotheosis of humans who contributed to human utility by the discovery of new fruits that they had discovered during their travels" (Prodicus adsumptos in deos loquitur qui errando inventis novis frugibus utilitati hominum profuerunt, Minucius Felix Oct. XXI.2). 
The chorus promises to offer a correct explanation (note the double repetition of o $\rho \theta \hat{\omega} \varsigma$ which alludes to Prodicus' obsession with the "correctness of names", DK 84 A11) of celestial things and the origin of primordial beings, including gods and rivers. The dismissive reference to Prodicus in the following verses suggests that his own account on the same topics is replaced by the cosmogony of the birds. ${ }^{37}$ They claim to be older and thus superior to the earliest gods (Aristophanes Au. 701-703; cf. 468-469). They also stress their usefulness to humankind as romantic gifts, seasonal indicators, messengers of prophecies, and givers of bounty ( $A v$. 704-736). Although Prodicus placed humans first, followed by the material and anthropomorphic divinities that humans invented, the birds appear to be prior to both mortals and immortals. Aristophanes elsewhere includes Prodicus among "the present experts in celestial things" ( $\tau \hat{\omega} v$ vôv $\mu \varepsilon \tau \varepsilon \omega \rho \circ \sigma o \varphi \iota \sigma \tau \hat{\omega} v$, DK 84 A5), thus implying that he was somehow concerned with issues pertaining to astronomy-cumtheology, like the Socrates ridiculed in the Clouds. ${ }^{38}$ Prodicus' interest in celestial bodies is confirmed by Sextus Empiricus and Epiphanius who include the sun and the moon among the useful things which, according to Prodicus, were deified by the earliest humans (DK 84 B5 = Sextus Empiricus M. IX.18; cf. IX.39, 52; Epiphanes $A d v$. Haer. III.21). Hence Prodicus' reputation as an "expert in celestial things" may be based primarily on his claim that celestial bodies have been wrongly honoured as gods.

Having established that Xenophon and Aristophanes enrich our limited

37. The surrounding verses (Aristophanes $A u$. 685-722) may contain some ironic allusions to Prodicus, but, given the lack of evidence concerning Prodicus' cosmogony, we cannot know to what extent Aristophanes parodies his doctrines ( $c f$. Mayhew 2011 p. 171-175). It is worth noting that the birds (namely the new gods) boast that their movements signal the seasonal changes and instruct humans to perform the proper acts in agriculture, sailing, animal husbandry, and trade (Ar. $A u .709-715)$. The reference to the tasks of farmers and shepherds alludes to Prodicus who traces the origins of religious belief in the veneration of the physical entities and forces connected with agriculture. Aristophanes is credited with a fragmentarily preserved work entitled the Seasons, which seems to refer to an agrarian utopia or a sort of golden age in which fruits are available during all seasons (Aristophanes frs. 577-589 K-A). It has been suggested (Ambrose 1983 p. 137-138; Mayhew 2011 p. 247-248) that the title indicates some connection with Prodicus' Seasons, since the longest fragment consists of a fifteen-lines debate between two unknown figures in which the first suggests that Athens enjoys products in any season of the year because the locals revere the gods (Aristophanes fr. 581 K-A). Further evidence that Aristophanes was familiar with Prodicus' Seasons can be found in the Clouds 889-1114: the contest between the "weaker" argument and the "stronger" argument, which are presented to the young Pheidippides as alternatives of education, reflects the diametrically opposite exhortations of Virtue and Vice to Heracles. Cf. Papageorgiou 2004 p. 64-69.

38. Dunbar 1995 p. 434, notes: "To the ordinary Athenian citizen an interest in $\tau \grave{\alpha} \mu \varepsilon \tau \varepsilon ́ \omega \rho \alpha$ connoted not simply a willingness to waste time on useless knowledge but a deplorable inclination towards impious scepticism as to the divinity of earth, sun, moon and stars, which for the traditionalist were powerful gods but for many philosophers were lifeless matter". 
knowledge as to Prodicus' theory, let us turn to the third contemporary of Prodicus who provides some evidence for his method. Prodicus is mainly known for the conceptual distinctions that he makes in Plato's early dialogues. ${ }^{39} \mathrm{He}$ is typically concerned with a couple of synonymous terms and endeavours to find out the basic meaning which they share and then to clarify the precise meaning of each term by providing examples. By making these subtle conceptual distinctions, Prodicus can show those who wish to be instructed in rhetoric what term is appropriate in each occasion and how they can avoid ambiguities. To be sure, his interest in synonymics presupposes sufficient knowledge of three interrelated issues: (a) the division of similar words (as Aristotle confirms in the Topics, DK 84 A19); (b) the distinction between the conventional use of a word and its original meaning (as Sextus Empiricus implies in referring to the metonymic use of words, DK 84 B5 = Sextus Empiricus M. IX.18); and (c) the etymology of words (which is part of the investigation into "correctness of names" to quote Plato's Cratylus, DK 84 A11), a process which reveals the origin of words and helps us to revise their common use in many cases.

Although the extant sources provide no direct evidence that Prodicus used etymology as a method to support his explanation of the origins of religious belief, a report of Galen encourages such a hypothesis. In On the Nature of Man, Prodicus appears to note that the term $\varphi \lambda \varepsilon^{\prime} \gamma \mu \alpha$ ("phlegm"), which is widely used for the cold and moist humour (e.g. Hippocrates Morb. Sacr. 9; Aristotle Prob. 862b28), contains a contradiction: it derives from $\pi \varepsilon \varphi \lambda \varepsilon \dot{\varepsilon} \chi \theta \alpha \mathrm{l}$ (the perfect infinitive passive of $\varphi \lambda \varepsilon_{\gamma} \varepsilon \mathrm{\varepsilon v}=$ "to burn"), which in fact refers to something subject to heat. In order to restore linguistic propriety, Prodicus suggests the term $\beta \lambda \varepsilon \varepsilon_{v \alpha \alpha}$ ("mucus") as more appropriate for designating the cold and moist humour (DK 84 B4). Underlying this proposal is the view that an expert in synonymics should review linguistic misuses and reveal the original meaning of words. This investigation might have led Prodicus to infer that a set of divine names reflect the gratitude of humans to the blessings of nature and the achievements of culture heroes.

Indeed, Philodemus castigates the attempts of Prodicus and other alleged atheists to etymologise divine names by modifying the original wording. ${ }^{40}$

39. DK 84 A11-19 with Mayer 1913 p. 22-41.

40. Philodemus Piet. PHerc. 1077, col. XIX = 519-541 Obbink: "Epicurus reproached those who eliminate the divine from existing things for their complete insanity, as in Book Twelve [sc. of On Nature] he reproaches Prodicus, Diagoras, Critias, and others, saying that they rave like lunatics, and he likens them to Bacchant revellers, admonishing them not to trouble or disturb us. For they make punning alterations in the names of gods, just as Antisthenes, substituting the most common [name of god?], ascribes the particular ones to imposition and even

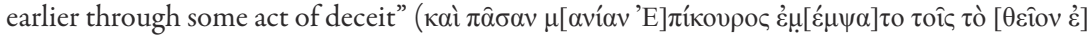

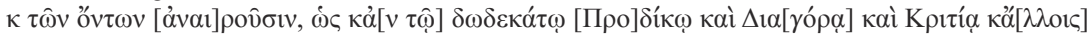

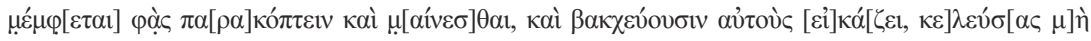


Similar attempts are documented in contemporary texts, including Plato's Cratylus and the Derveni papyrus, as well as in fragments pertaining to Stoic theology. ${ }^{41}$ The name Demeter constitutes a good example of how Prodicus used his linguistic skills to conclude that some gods originate from human experience. The etymology reveals that Demeter is understood as the "earth mother" $\left.\left(\delta \hat{\eta}+\mu \eta^{\prime} \tau \rho\right)\right)^{42}$ or the "grain mother" ( $\delta \eta \alpha \grave{\imath}=$ "barley"; $c f$. Etymologicum Magnum 264.13). Moreover, the epithets attributed to the goddess indicate that the repeated cycles of vegetation motivate humans to assume that a sort of benevolent mother supplies them with nourishment. ${ }^{43}$ They thus depict Demeter as an inexhaustible and universal source of fertility. It is not accidental that she is also called "the law-giving Demeter" (Herodotus VI.91; Diodorus Siculus V.68.1-3), and she is supposed to have introduced both the art of agriculture and the mysteries in Athens (Hymni Homerici IV.256-495; Isocrates IV.28). The chief protector of agriculture is thought to be the generator of social institutions, thus confirming Prodicus' theory concerning the primacy of agriculture over other cultural conquests.

\section{Prodicus and the theological debates of Hellenistic philosophers}

After connecting Prodicus' theory with the reports of his contemporaries, the next step is to trace its reception in the Hellenistic era from which derives most of the surviving evidence. Both the Epicureans and the Stoics were interested in Prodicus' explanation of the origins of religious belief, but they disagreed as to his contribution to theology: the former thought that Prodicus espouses atheism, whereas the latter that he partially anticipates their arguments for the existence and benevolence of the god.

To begin with the principal source, in On Piety Philodemus criticises the

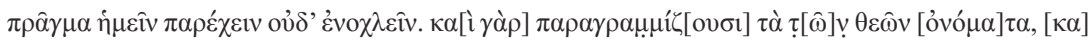

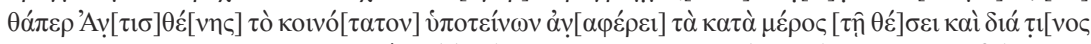

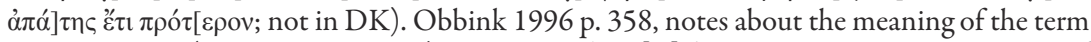
$\pi \alpha \rho \alpha \gamma \rho \alpha \mu \mu^{\prime} \zeta \varepsilon v v(=\pi \alpha \rho \alpha \gamma \rho \mu \mu \mu \alpha \tau i \zeta \varepsilon t v):$ "its principal use [...] denotes a punning interpretation of a name or word by means of alliterative transposition, addition, or substitution of consonants".

41. On Plato Crat. 400d1-408d5, which contains etymologies of various divinities, including Demeter and Dionysus, see Sedley 2003. On the Derveni papyrus see col. XIV on Cronus and col. XXII on Earth and Demeter. On Stoic etymologies the main source is Cornutus' theological treatise; on Zeno of Citium see SVF I 100 on the Titans; on Cleanthes see SVF I 540 and 546 on Apollo and Dionysus respectively; on Chrysippus see SVF II 1021 on Zeus, Athena, Hera, Hephaestus, Poseidon, and Demeter.

42. PDerv. col. XXII.7-11: "She was called Ge by convention. Mother, because all things are born from her. Ge and Gaia according to each one's dialect. And she was called Demeter as the Earth Mother, one name from the two. For it was the same". Cf. Diodorus Siculus I.12.4; Sextus Empiricus M. IX.189; Cicero ND II.67.

43. E.g. "fruit-bearing" (Aristophanes Ra. 384); "bringer of seasons, bestower of splendid gifts" (Hymni Homerici II.192); "child-nurturer, bestower of bliss, wealth-giving goddess, nourishing ears of corn, giver of all" (Orphei Hymni 40.2-3). 
conception of the divine in early Greek poetry and mythography and reviews the theological views of philosophers from Thales to Diogenes of Babylon. His aim is to show that the Epicurean theology is founded on a sound epistemological basis, thus attributing the charge of atheism to his main rivals, the Stoics. Philodemus mentions Prodicus on three occasions: when he defends Epicurus against the charge of atheism (Philodemus Piet. PHerc. 1077, col. XIX $=519-541$ Obbink); ${ }^{44}$ when he summarises Prodicus' theory in a critical survey of theological views (Piet. PHerc. 1428, fr. 19 Schober; the corresponding section is omitted in Cicero's doxographical account); ${ }^{45}$ and when he condemns Persaeus for approving Prodicus' theory (DK 84 B5 $=$ Piet . PHerc. 1428, cols. II.28-III.13 Henrichs; $c f$. Cicero ND I.38). ${ }^{46}$ I have examined briefly these reports in connection with Prodicus' theory. I will now focus on how Epicurus and Persaeus understood his anthropological interpretation of religion.

The earliest known reference to Prodicus' theory is credited to the founder of Epicureanism. Although Epicurus was often criticised for his mechanistic explanations of natural phenomena, he argued that the gods exist but their features are different from what we commonly believe. They are imperishable and blessed beings who live in intermundane places and are detached from the innumerable worlds and their inhabitants, while humans are mortal beings and should strive to free themselves from mental anxiety and fear of death (Epicurus Ep. Men. 123-124; Cicero ND I.43-51). In virtue of their imperishability and blessedness, the gods are neither involved in human affairs nor in the creation and workings of the cosmos (Epicurus Ep. Hdt. $76-77, K D$ 1). Knowledge of the divine is acquired through "preconception" ( $\pi \rho{ }^{\prime} \lambda \eta \psi 1 \varsigma$ ), which is shared by all humans (Cicero ND I.43-45) and results from a constant stream of similar images received in sleep (Sextus Empiricus $M$. IX.25, 43-47; Lucretius $D R N$ V.1169-1182). We are naturally constituted in such a way as to acquire the preconception of gods with clarity, and so those who deny the existence of the gods depart from the universal consensus. ${ }^{47}$

In the twelfth book of On Nature, from which we possess a few citations, Epicurus deals with the rise of civilization and the formation of social institutions, including religion. He explains how the earliest humans formed the conception of gods as imperishable external entities (Philodemus Piet. PHerc. 1077, col. VIII = 225-231 Obbink). His account of the origins of religious belief includes a critical survey of thinkers who propose on various grounds

44. See above p. 143-144, n. 40.

45. See above p. 131.

46. See above p. 132.

47. It is contested as to whether the Epicureans believe that we acquire knowledge of the gods independently from experience or not. See Tsouna 2016 p. 174-185. 
that the gods are but a human invention. ${ }^{48}$ Apart from Prodicus, Epicurus attacks Diagoras of Melos, who has been outlawed by Athens for satirising the Eleusinian mysteries, as well as Critias, who has argued that religion is a legislator's construction designed to prevent people from breaking the law. ${ }^{49}$ We know few things about the theological views of Diagoras of Melos, the most notorious atheist of antiquity, ${ }^{50}$ but both Prodicus and Critias trace the origins of religious belief in a primitive stage of human history. Epicurus seems to have refuted their doctrines by providing his own explanation as to the attitude of the earliest humans towards the natural world and the reception of the divine. Epicurus' black list, which presumably included more thinkers such as Protagoras ( $c f$. Diogenes Oenoanda fr. 16, cols. II-III Smith), is the earliest known attempt to record the ancient atheists. ${ }^{51}$

Epicurus accuses his rivals of denying the existence of the gods, manipulating divine names, and behaving like the participants in Bacchic rites. It is not clear what exactly Epicurus means by using this bizarre comparison. It may be interpreted as a rhetorical way of stressing the insufficient argumentation of his rivals. They modify divine names by proposing absurd etymologies, like the Stoics, and so behave in the short of strange manner that recalls the ecstasised advocates of Dionysus. Their insanity lies in the fact that they ignore the preconception of gods imprinted in the mind of all humans. ${ }^{52}$

Although Epicurus condemned Prodicus' theory as irrational, Persaeus found it somewhat convincing in his On Gods (DK 84 B5 = Philodemus Piet. PHerc. 1428, cols. II.28-III.13 Henrichs). This is confirmed by Cicero (DK 84 B5 = Cicero ND I.38) and Minucius Felix (Oct. XXI.2-3), both of

48. Obbink 1989.

49. On Diagoras of Melos see Winiarczyk 2016. Critias formulates his theory in the Sisyphus fragment of a tragedy or satyr-play (DK 88 B25). Its authorship has been hotly debated (an overview of the debate can be found in Whitmarsh 2014, p. 109-115), since Sextus Empiricus, who quotes the fullest version of the text, attributes it to Critias $(M$. IX.54), while ps.-Plutarch ascribes it to Euripides (Plac. 879F, 880E-F = Aëtius I.6.7, I.7.2) who was often criticised for his bold views about the gods. On Euripides see Sassi in this volume, p. 169-191.

50. In Aristophanes' parody of current philosophical ideas, Socrates of Melos (a fictional Socrato-Diagoras; cf. Scholia in Aristophanem Nu. 830a-g) believes that Zeus has been succeeded by Whirl, thus proposing a wordplay with the main force in the Anaxagorean

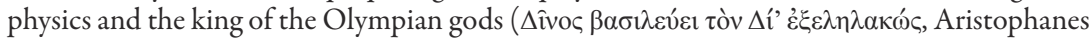
$N u .828$ ). The wordplay may be taken as an example of the fanciful etymologies advanced by the atheists criticised by Epicurus.

51. The first index atheorum may be credited to Theophrastus, whose doxographical work seems to have been used by Epicurus (Sedley 2013a, p. 329-330). On other catalogues of ancient atheists see Cicero ND I.117-9 (Diagoras of Melos, Theodorus of Cyrene, Protagoras, Critias, Prodicus, Euhemerus); Sextus Empiricus M. IX.50-8 (Euhemerus, Prodicus, Diagoras of Melos, Critias, Theodorus of Cyrene, Protagoras, Epicurus); ps.-Plutarch Plac. 880D-E = Aëtius I.7.1-2 (Diagoras of Melos, Theodorus of Cyrene, Euhemerus, Euripides).

52. Obbink 1996 p. 356-357; cf. Obbink 1992. 
whom attribute a Prodicean-like doctrine to Persaeus. It is worth noting that Philodemus refers to Persaeus' evaluation of what was written by Prodicus himself, thus implying that Persaeus had access to a work of his forerunner that was circulating during the Hellenistic era. ${ }^{53}$ Persaeus was one of the favourite pupils of Zeno of Citium (SVF I 435-438), the founding father of Stoicism, and was active in the middle of the third century BC. The fact that he joined the Stoa at an early age ( $S V F$ I 439), the composition of a treatise entitled On Impiety (SVF I 435), and the absence of reports regarding his atheism or agnosticism indicate that Persaeus raised no doubts as to the existence of the gods. Why, then, was Persaeus sympathetic to Prodicus' theory?

The Stoics, developing the Platonic ideas of the Timaeus and the Laws, put forward a physical theology which is built on the idea that a single rational divinity pervades the entire cosmos, participates actively in its creation and administration, and exercises providential care towards living beings, especially humans. ${ }^{54}$ The Stoics thus emphasise the tight bond between the divine and the human spheres, in contrast to the Epicureans who believe that the gods play no role in human and cosmic affairs. ${ }^{55}$

According to the Stoics, the conception of the divine is engraved in the human mind on the basis of repeated experience of the natural world which has an orderly and beneficent structure. In order to prove this theory, the Stoics provide a series of explanations which attempt to answer how we obtain the conception of the divine. ${ }^{56}$ To begin with a well-known text, the Stoic spokesman in Cicero's De natura deorum notes that Cleanthes, a contemporary of Persaeus, refers to the following facts: first, the foreknowledge of future events (argument from divination); second, the temperate climate, the earth's fertility, and the abundance of other blessings (argument from providence; $c f$. the first stage of Prodicus' theory); third, the awe induced by natural phenomena such as floods and earthquakes (argument from fear); fourth and foremost, the orderliness of nature, especially the regularity of revolutions in the heaven and the beauty of celestial bodies (argument from design). Consideration of these facts suggests that they are not products of accident but that there is a superior divine force underlying the rational construction and steering of the cosmos, just as, if one enters a building where everything is put in perfect order, one will conclude that there is a human mind in control of everything (SVF II $528=$ Cicero ND II.13-5). In

53. The circulation of the Seasons is confirmed by the scholiast to Aristophanes' Clouds (DK 84 B1). Cf. Mayhew 2011 p. 196.

54. For an overview of Stoic theology see Algra 2003.

55. The following report provides a good example of this dispute: "[sc. Chrysippus] fights against Epicurus and against those who deny providence, basing this attack on the conceptions that we have of the gods for we conceive of them beneficent and philanthropic" (SVF II $1115=$ Plutarch St. rep. 1051E).

56. SVF II 1009-1020. Detailed discussion in Dragona-Monachou 1976. 
a similar vein, ps.-Plutarch reports seven reasons given by the Stoics for the formation of the conception of the divine (SVF II 1009 = ps.-Plutarch Plac. 880A-D = Aëtius I.6.10-6). The first concerns the harmonious revolutions of celestial bodies, the succession of day and night, and the seasonal cycle that encourages humans to regard the heaven and the earth as a sort of father and mother respectively, since the heaven fertilises the earth and latter in turn supplies humans with goods ( $c f$. the first stage of Prodicus' theory). The seventh refers to the deification of great benefactors of the past, like Heracles, Dionysus, and the Dioscuri ( $c f$. the second stage of Prodicus' theory).

Taking into account these reports, it is reasonable to assume that the primary aim of Persaeus was to argue for divine providence, and so he was interested in Prodicus' theory for this very reason. Although Prodicus implicitly undermines the existence of some gods by revealing their actual status and downgrading them to commodities and benefactors, Persaeus finds in the anthropological interpretation of his forerunner some elements of an argument for defending the existence and benevolence of the god. Persaeus thinks that by deifying initially useful things and then the inventors of these things, the earliest humans conceived a fundamental aspect of the divine: its providential care about humankind. ${ }^{57}$ By deifying the sun and the rivers and identifying grain with Demeter, for instance, they recognized the manifestation of an all-pervading force that animates the seasonal cycle and sustains them continuously. For Persaeus the veneration of commodities and benefactors at the dawn of civilization shows that even in a primitive stage human mind is structured to seek the divine and grasp one of its essential features. Thus the belief in superhuman controlling powers is part and parcel of our nature as rational beings who are made to contemplate the marvellous works of god.

To be sure, the Stoic view as to the active involvement of god in human and cosmic affairs is inconsistent with Epicurean theology. By adopting Prodicus' theory that Demeter and Dionysus provide agricultural blessings and so inspire humans to recognize and venerate them, Persaeus assumes that the gods trouble themselves with the administration of the seasonal cycle and the growth of crops instead of living in uninterrupted tranquillity far away from our own world with its complex settings and evident imperfections ( $c f$. Cicero ND I.51-54; Lucretius DNR V.195-234). From an Epicu-

57. Algra 2003 p. 158-159. The Stoic spokesman in Cicero's De natura deorum notes about the deification of commodities: "Many other divinities, however, have with good reason been recognized and named both by the wisest men of Greece and by our ancestors from the great benefits that they bestow. For it was thought that whatever confers great utility on humankind must be due to the operation of divine intelligence towards humans. Thus sometimes a thing sprung from a god was called by the name of the god himself, as when we speak of corn as Demeter and of wine as Dionysus [...] " (ND II.60). On the deification of benefactors, like Heracles, the Dioscuri, Asclepius, and Dionysus, see Cicero ND II.62. 
rean perspective, this means that Persaeus, like other Stoics, deprives the gods of their essential features, namely imperishability and blessedness, as Philodemus notes in his critique of Persaeus' theology (DK 84 B5 = Philodemus Piet. PHerc. 1428, cols. II.28-III.13 Henrichs).

\section{Conclusion}

It is time to draw some tentative conclusions regarding Prodicus' contribution to the intellectual debates of antiquity. If we set apart the biographical reports, approximately half of the remaining sources concerning Prodicus' doctrines derive from the Platonic dialogues. Plato consistently presents his contemporary as a hunter of wealthy pupils and an expert in synonymics. Nevertheless, the various texts examined in this paper contradict rather than confirm the monolithic presentation of Plato. A combination of the reports of Xenophon, Aristophanes, Themistius, and several Hellenistic philosophers shows that an important aspect of Prodicus' work is investigation into the genesis of social institutions, the interconnection between agriculture and religion, and the formation of moral values and culture heroes. Prodicus appears to be one of the first "historians of civilization", adhering to the tradition established by various fifth-century thinkers, rather than a teacher merely preoccupied with linguistic issues. It is not unreasonable to assume that this is part and parcel of a wider investigation into the origin of language and the conventional use of words, including divine names. ${ }^{58}$ The results of this multifaceted research into cultural conquests were presented in the Seasons and displayed publicly, as the speech concerning "Heracles' choice" shows. However, Prodicus' rationalistic attitude towards some benefactor gods, especially those associated with agriculture, seems to have been detached from its original context and interpreted in different ways by Hellenistic philosophers. Instead of grouping Prodicus along with other notorious atheists of antiquity or viewing him as an early exponent of divine providence, as the Epicureans and the Stoics did respectively, it is more instructive to understand his explanation of the origins of religious belief in the light of other accounts of cultural evolution.

58. The origin of language is briefly examined in the cultural narratives attributed to Democritus (DK 68 B5.1 = Diodorus Siculus I.8.2-3) and Protagoras $($ DK 80 C1 = Plato Prot.322a5-6). 


\section{BIBLIOGRAPHY}

Algra, K. 2003 : « Stoic Theology », dans B. Inwood (éd.), The Cambridge Companion to the Stoics, Cambridge, 2003, p. 153-178 (Cambridge Companions to Philosophy).

Ambrose, Z. P. 1983 : « Socrates and Prodicus in the Clouds », dans J. P. Anton \& A. Preus (éd.), Essays in Ancient Greek Philosophy, vol. II, Albany (New York), 1983, p. 129-144.

Bremmer, J. N. 2007 : « Atheism in Antiquity », dans M. Martin (éd.), The Cambridge Companion to Atheism, Cambridge, 2007, p. 11-26 (Cambridge Companions to Philosophy).

Cole, T. 1967 : Democritus and the Sources of Greek Anthropology, Cleveland (Ohio), 1967 (Amer. Philol. Assoc. Monogr., 25).

Diels, H. \& W. Kranz 1951-1952 (éd.) : Die Fragmente der Vorsokratiker, vol. 1-3, Berlin, 1951-1952.

Dodds, E. R. 1960 (éd.) : Euripides, Bacchae : Edition with Introduction and Commentary, 2nd ed. rev., Oxford, 1960.

Dorion, L.-A. 2008 : « Héraklès entre Prodicos et Xénophon », Philosophie Antique, 8 (2008), p. 85-114.

Dragona-Monachou, M. 1976 : The Stoic Arguments for the Existence and the Providence of the Gods, Athens, 1976 (National \& Capodistrian Univ. of Athens, Fac. of Arts S. Saripolos' Library, 32).

Dunbar, N. 1995 (éd.) : Aristophanes, Birds, ed. with an introd. \& comm., Oxford, 1995.

Gagarin, M. 1973 : «Dike in the Works and Days », Classical Philology, 68 (1973), p. 81-94.

Gray, V. 2006 : « The Linguistic Philosophies of Prodicus in Xenophon's Choice of Herakles ? », Classical Quarterly, N. S. 56/2 (2006), p. 426-435.

Guthrie, W. K. C. 1969: A History of Greek Philosophy, vol. III : The Fifth Century Enlightenment, Cambridge, 1969.

Henrichs, A. 1975 : « Two Doxographical Notes : Democritus and Prodicus on Religion », Harvard Studies in Classical Philology, 79 (1975), p. 93-123.

- 1976: «The Atheism of Prodicus », Cronache Ercolanesi, 6 (1976), p. 15-21.

- 1984: «The Sophists and Hellenistic Religion : Prodicus as the Spiritual Father of the Isis Aretologies », Harvard Studies in Classical Philology, 88 (1984), p. 139-158.

Jaeger, W. 1947 : The Theology of the Early Greek Philosophers, Oxford, 1947.

Laks, A. \& G. W. Most 2016 (éd.) : Early Greek Philosophy, edited and translated, in collaboration with G. Journée and assisted by D. Lévystone, vol. VIII: Sophists, Part 1, Cambridge (Mass.), 2016 (Loeb Classical Library, 531).

Manuwald, B. 2013 : «Protagoras' Myth in Plato's Protagoras : Fiction or Testimony ? », dans J. M. van Ophuijsen, M. van Raalte \& P. Stork (éd.), Protagoras of Abdera : The Man, His Measure, Leiden, 2013, p. 163-177 (Philosophia Antiqua, 134).

Mayer, H. 1913 : Prodikos von Keos und die Anfänge der Synonymik bei den 
Griechen, Paderborn, 1913 (Rhetorische Studien, 1).

Maynew, R. 2011 (éd.) : Prodicus the Sophist: Texts, Translations, and Commentary, Oxford, 2011.

Nestle, W. 1936 : « Die Horen des Prodikos », Hermes, 71 (1936), p. 151-170.

- 1942 : Vom Mythos zum Logos : Die Selbstentfaltung des griechischen Denkens von Homer bis auf die Sophistik und Sokrates, $2^{\text {nd }}$ ed. rev., Stuttgart, 1942.

Оввіnк, D. 1989 : « The Atheism of Epicurus », Greek, Roman and Byzantine Studies, 30 (1989), p. 187-223.

- 1992 : "What All Men Believe Must Be True" : Common Conceptions and consensio omnium in Aristotle and Hellenistic Philosophy », Oxford Studies in Ancient Philosophy, 10 (1992), p. 193-231.

- 1996 (éd.) : Philodemus, On Piety, Part I, Critical Text with Commentary, Oxford, 1996.

— 2001: «Le livre I du De natura deorum de Cicéron et le Depietate de Philodème », dans C. Auvray-Assayas \& D. Delattre (éd.), Cicéron et Philodème : la polémique en philosophie, Paris, 2001, p. 203-225 (Études de littérature ancienne, 12).

Papageorgiou, N. 2004 : « Prodicus and the Agon of the Logoi in Aristophanes' Clouds », Quaderni Urbinati di Cultura Classica, N. S. 78 (2004), p. 61-69.

SAnsone, D. 2004 : « Heracles at the Y », Journal of Hellenic Studies, 124 (2004), p. $125-142$.

- 2015 : « Xenophon and Prodicus' Choice of Heracles », Classical Quarterly, N. S. 65/1 (2015), p. 371-377.

Schober, A. 1988 (éd.) : « Philodemi Depietate, Pars prior », Cronache Ercolanesi, 18 (1988), p. 67-125.

Sedley, D. N. 2003 : Plato's Cratylus, Cambridge, 2003 (Cambridge Studies in the Dialogues of Plato).

- 2013a : «The Atheist Underground », dans V. Harte \& M. Lane (éd.), Politeia in Greek and Roman Philosophy, Cambridge, 2013, p. 329-348.

- 2013b : « From the Pre-Socratics to the Hellenistic Age », dans S. Bullivant \& M. Ruse (éd.), The Oxford Handbook of Atheism, Oxford, 2013, p. 139-151.

SOVERINI, L. 1998 : Il sofista e l'agorà : sapienti, economia e vita quotidiana nella Grecia Classica, Pisa, 1998 (Pubblicazioni della Classe di Lettere e Filosofia / Scuola Normale Superiore, Pisa, 19).

Tordesillas, A. 2008 : « Socrate et Prodicos dans les Mémorables de Xénophon », dans M. Narcy \& A. Tordesillas (dir.), Xénophon et Socrate : actes du colloque d'Aix-en-Provence (6-9 novembre 2003), suivis de Les écrits socratiques de Xénophon: supplément bibliographique (1984-2008) par Louis-André Dorion, Paris, 2008, p. 87-110 (Bibliothèque d'histoire de la philosophie. Nouvelle série).

Tsouna, V. 2016 : « Epicurean Preconceptions », Phronesis, 61/2 (2016), p. $160-221$.

Untersteiner, M. 1961 (éd.) : Sofisti, Testimonianze e frammenti, vol. II: Gorgia, Licofrone e Prodico, Firenze, 1961 (Biblioteca di studi superiori).

Whitmarsh, T. 2014 : «Atheistic Aesthetics : The Sisyphus Fragment, Poetics and the Creativity of Drama », Cambridge Classical Journal: Proceedings of the Cambridge Philological Society, 60 (2014), p. 109-126.

- 2015 : Battling the Gods: Atheism in the Ancient World, New York, 2015. 
WiniarczyK, M. 1976 : « Der erste Atheistenkatalog des Kleitomachos », Philologus, 120 (1976), p. 32-46.

- 2013: The Sacred History of Euhemerus of Messene, Berlin, Boston, 2013 (Beiträge zur Altertumskunde, 312).

- 2016 : Diagoras of Melos: A Contribution to the History of Ancient Atheism, translated from Polish by Witold Zbirohowski-Koscia, Berlin-Boston, 2016 (Beiträge zur Altertumskunde, 350). 